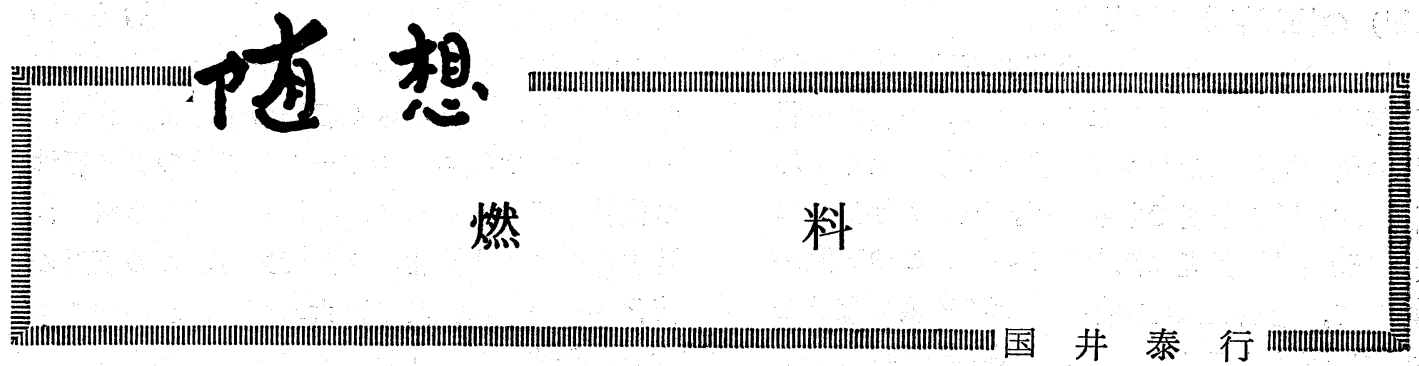

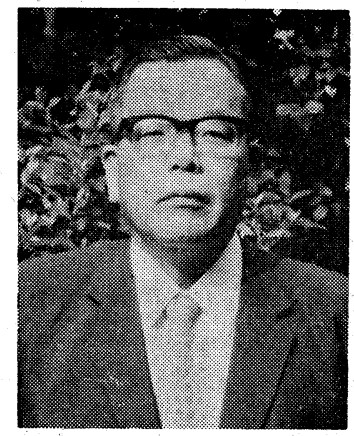

約 4 年前のオイル ショック以来, わが 国はもちろん世界各 国でエネルギー問題 がやかましく取り上 げられている。わが 国に执いては，昭和 50 年 8 月通商産業省 に, 総合エネルギー 調査会が「昭和50年代エネルギー安定政策」を 答申し, 同年12月各関係閣僚からなる閣僚会議 がエネルギー政策の基本方向を政策大綱として まとめた。民間においても各関係先において調 查論議されて括り, 新聞, 雑誌その他マスコミ 全般に拈いては毎日のように紙面を賑わし，ま たラジオ, テレビでも PR されている。まさ に世をあげてエネルギー時代といっても過言で はあるまい。

当協会の定款によれば，「燃料とはエネルギ 一および工業原料としての然料をいうものとす る」とうたわれて扣り, 現在のエネルギー時代 に最も脚光を浴びている協会として, 社会的使 命は重大であることは今更いらまでもない。す なわち，本会の目的として「然料に関する科学 および技術の進歩発達を図り, もって産業経済 および科学技術の発展に寄与するとともに国民 生活の向上に貢献することを目的とする」と定 められている。

私は石油精製会社すなわら燃料に関係する会 社の一員として，エネルギー源の将来はどうな るのであろらかと常に悩まされている。エネル ギー源として考えられているものは，第一に非
枯渴的なエネルギー源として太陽熱, 地熱, 潮 力, 風力などが挙げられ，第二に枯渴し更新さ れないエネルギー源として化石然料扣よび核然 料が挙げられる。これらのエネルギー源のらち で, 石油, 石炭，核然料について簡単にふれて みたい。

\section{石 油}

石油資源の将来はどうなるのであろらか。今 から十数年前, アメリカの有名な学者が将来原 油の価格はバーレル当たり 1 ドルになると宣伝 していた。当時原油の価格はバーレル当たり 2 ドル前後であったが, 今後生産量は大いに増加 し，価格は下降してゆくと宣伝されたことが思 い出される。その後アラブとイスラェルとの戦 争により，アラブは武器として石油をとりあ げ, 対米輸出禁止に踏み切った。その後戦争解 決と同時に, あの 4 年前の原油価格の約 5 倍の 值上げにより，世界的なオイルショックを引き 起こした。石油が戦争および経済的な武器とし て大いに威力を発揮する事実を見せつけられ て，世をあげてェネルギー時代になってきた。

しからば将来の石油の生命はいつまで続くの であろらか。昔から石油の生命は約30年といわ れているが, 現在でも約30 40年といわれてい る。現在の石油の究極可採埋蔵量は世界全体で 約 2 兆 $\mathrm{bbl}$ で, その内自由世界全体の埋蔵量 は約 1.5 兆 bbl とみられている。これまでの世 界全体の累積生産量は約 3,400 億 $\mathrm{bbl}$ であり, 現在の確認埋蔵量は約 6,600億bbl であるの で, 今後に残されている未発見埋蔵量は約 1 兆 bbl とみなされている。自由世界の確認埋蔵量 (約 5,600億bbl) は現在の生産量（約 150 億 
bbl）の約37年分に相当する。

以上の推定をとれば，今後の石油の生命は約 37年以内に危機が来ることになる。現在自由世 界の新規発見量のテンポは過去 30 年間で年平均 約 180 億bbl 程度であったが, 最近 5 年間では 約 150億bbl 程度に減少している。この事実か らして, 産油国は可採年数が 15 年程度になると 生産抑制をとるとすれば，1980年後半ないし 1990年前半頃生産をダウンし輸出を抑制する可 能性があろう。しかし, 石油の埋蔵量について は現在の探鉱技術が将来どの程度進歩するので あろらか。探鉱技術者に笑われるかも知れない が，技術革新はあり得ないのであろらか。また 採油技術についても現在の回収率は約20 30\% 程度と聞くが，これまた革新的に飛躍しないの であろらか。今後の技術の発展に期待したい。

上記石油の資源の有限性から, 石油資源をほ とんど持たないわが国の将来はいかにあるべき か。エネルギー需要の約 $70 \%$ を石油に依存し ているわが国としてはもちろん輸入に頼らざる を得ない。第一次大戦の最中, フランスの大統 領クレマンソーが「石油の一滴は血の一滴」と 叫んだ悲痛な言葉は，現在のわが国にもあては まる名言であるといえよう。日本国民として考 えたくない戦争には石油は不可欠であり，また 平和な時代には国民経済の血液である。今まで の日本は世界平和に恵まれて，資源を持たない 有利性を活用して経済大国を築き上げてきた。 すなわち，工業に必要な生産原料は世界中の資 源保有の各国の競争下で最も有利に輸入出来る 立場にあった。しかし，今後この経済大国を維 持発展させてゆくためには, 世界平和の旗印の 下に資源保有国と政治，経済的協調が今まで以 上に益々重要になってくる。技術的には，石油 資源の減少に対処して, 石油然料に頼らざるを 得ない内燃機関用燃料を，原油から得率を上げ て得るよう大いに努力する必要がある。すなわ ら重質留分のクラッキングによる軽質油化が要 求される。

\section{石炭}

石油の代替エネルギーとして埋蔵量の多い石
炭は確認埋蔵量約 1.4兆 $\mathrm{t}$ 可採埋蔵量約 5,900 億 $\mathrm{t} て ゙$, 現在の年産量より算出すれば約 190 年 の命となる。したがって石油の生命より長く, 将来, 一般の熱エネルギーとしてそのまま石油 の代替が可能であるが，内燃機関用の燃料に代 替するにはまず液化が必要である。この石炭の 液化については, 第二次大戦当時, わが国でも 大いに研究され，工業生産に入って間もなく， 終戦となった。その後, オイルショック以来再 び研究が進められているが, 石炭を液化し, 単 に燃料とするのではなく，内燃機関燃料および 潤滑油の生産についても大いに収率の向上をは かる今後の研究に期待したい。

\section{核燃 料}

次に核然料として在来型炉を主体に考える と, 核燃料として天然ウランの埋蔵量が主体と なる。1976年時点で 380 500万 $\mathrm{t}$ と見込まれ るが, 在来型炉の利用率約 $2 \%$ に対し, 高速 増殖炉の利用率は 60 70\% になることから も, 課題は今後の技術開発の動向にあるといえ る。な打，核融合炉の燃料としての重水素は海 水中の資源としてばく大な量が存在する。現状 は基礎的な技術開発の段階にあり, 今後の開発 が期待される。核然料の使用については公害お よび安全上の種々の社会的問題が引き起こされ ているが, エネルギーの重要性の認識と技術開 発によって克服されることと思う。今後将来, 政治的, 経済的な世界の競争下においては, 核 然料は最もエネルギーの中で占める地位が高く なるのではなからうか。現在すでにこれを見越 しての核燃料保有国のカルテル問題や再処理問 題が提起されている。「石油は血の一滴」の言 葉は将来核然料に置き換えられるのではなかろ らか。

以上資源有限然料である石油, 石炭, 核然料 についてふれたが，その他のエネルギー源もも ちろんのことであるが, 省エネルギー対策も含 めて，今後の技術の開発とあいまって政治的, 経済的要素の交錯により，エネルギー政策が方 向づけられてゆくものと思われる。

（三菱石油常務取締役・本会理事） 